\title{
Implementasi Learning Cycle 5E Dalam Pembelajaran Pendidikan Agama Hindu dan Budi Pekerti Pada Siswa Kelas X SMAN 1 Rendang Karangasem
}

\author{
Ni Ketut Sri Kusuma Wardhani', Ni Wayan Yusi Armini ${ }^{2}$ \\ ${ }^{12}$ Universitas Hindu Negeri I Gusti Bagus Sugriwa Denpasar \\ ${ }^{1}$ sriekusuma@uhnsugriwa.ac.id, ${ }^{2}$ yusiarmini@uhnsugriwa.ac.id
}

\begin{abstract}
The covid-19 pandemic has significantly influenced the educational field where all instructional processes are shifted to online learning. This study aims to analyze strategy, problems, and implication of the implementation of $5 E$ learning cycle on religious studies and character education of the tenth graders of SMAN 1 Rendang Karangasem during the Covid-19 pandemic. The 5E learning cycle is an application of constructivist approach covering engagement, exploration, explanation, elaboration, and evaluation. This study employs a phenomenological approach where the data is gathered through observation, in-depth interview, literature studies, and documentation studies which are futher analyzed descriptive qualitatively. The study results in showing that the implementation of $5 E$ model begins with the construction of the lesson plan, until the evaluation process. Generally, 5E cycle is conducted online through google classroom, zoom meeting, whatsapps groups, youtube, and educational radio. Further, several problems are found by teachers are mainly because of two factors, they are internal covering biological and psychological aspects, and also external factors including school, family, as well as the infrastructure. The implementation of $5 E$ model has a positive implication in improving students' ability to master a concept through discussion, motivation of and creativity of the teachers and students, and administer the Tat twam asi principle, confidence, and social care. In short, the implementation of 5 E learning cycle is has a positive implication toward students' ability in learning religious studies and character education.
\end{abstract}

Keywords: 5E Learning Cycle; Covid-19 Pandemic; Religious Studies

\begin{abstract}
Abstrak
Pandemi Covid-19 berpengaruh secara signifikan terhadap dunia pendidikan dimana seluruh proses pembelajaran dialihkan secara daring. Penelitian ini bertujuan untuk menganalisis strategi, kendala, dan implikasi penerapan model pembelajaran Learning Cycle 5 E pada mata pelajaran Agama Hindu dan Budi Pekerti siswa kelas X SMAN 1 Rendang Kabupaten Karangasem selama pandemic covid-19. Model Pembelajaran learning cycle 5E merupakan terapan teori konstruktivisme meliputi engagement, exploration, explanation, elaboration, evaluation. Penelitian menggunakan pendekatan fenomenologi dimana data dikumpulkan melalui observasi, wawancara mendalam, studi kepustakaan, dan studi dokumen yang kemudian dianalisis secara deskriprif kualitatif. Hasil penelitian menunjukkan bahwa penerapan 5E dimulai dari kegiatan pembuatan rencana pembelajaran hingga proses evaluasi. Secara umum, pelaksanaan 5E dilakukan secara daring melalui google classroom, zoom meeting, whatsapps group, youtube, dan radio edukasi. Lebih jauh, beberapa kendala yang dihadapi datang dari faktor internal yakni siswa dan guru secara biologis dan psikologis. Faktor eksternal mencakup lingkungan sekolah, keluarga, serta sarana pembelajaran. Implementasi model pembelajaran $5 \mathrm{E}$ berimplikasi positif terhadap peningkatan
\end{abstract}


kemampuan siswa dalam pemahaman konsep melalui diskusi, motivasi kreativitas guru dan siswa, pengamalan konsep tat twam asi, percya diri, serta kepedulian sosial. Dengan demikian, dapat disimpulkan bahwa penerapan model 5E secara daring berimplikasi positif terhadap kemampuan siswa dalam pembelajaran agama Hindu dan Budi Pekerti.

Kata Kunci: Pembelajaran Learning Cycle 5E; Pandemi Covid-19; Pendidikan Agama Hindu

\section{Pendahuluan}

Pendidikan merupakan modal dasar tumbuh dan berkembang sumber daya manusia yang berkualitas dalam menghadapi tantangan berbagai macam perkembangan dunia dengan kemajuan teknologi komunikasi. Pendidikan baik secara formal dan informal menjadi basis untuk meningkatkan kualitas peserta didik (Puspitorini, 2020). Pelaksanaan pendidikan maupun pembelajaran merupakan suatu usaha yang kompleks karena mencakup proses interaksi antara guru dan siswa, pembimbingan dan pengarahan peserta didik dalam rangka mencapai tujuan pembelajaran (Trianto, 2020).

Namun pandemic covid-19 telah memaksa pemerintah Indonesia untuk mengeluarkan berbagai kebijakan untuk meminimalisir penularan diberbagai sektor, termasuk dalam sektor pendidikan (Heliandry, 2020). Menteri Pendidikan dan Kebudayaan Republik Indonesia telah menerbitkan Surat Edaran Nomor 4 Tahun 2020, tertanggal 24 Maret 2020 tentang pelaksanaan kebijakan pendidikan dalam masa darurat penyebaran corona virus disease (COVID-19) bahwa pembelajaran dilaksanakan dengan pembelajaran Jarak Jauh (PJJ) atau secara daring pada satuan pendidikan dengan menggunakan berbagai sumber belajar melalui media teknologi informasi komunikasi. Hal ini dilakukan untuk memberikan pengalaman belajar yang bermakna bagi peserta didik dengan tetap memperhatikan tumbuh kembang kondisi psikososialnya.

Semenjak diberlakukannya pelaksanaan pembelajran di masa darurat Covid-19 pada tanggal 16 Maret 2020 Seluruh sekolah di Bali mengambil perubahan bentuk pembelajaran dari yang konvensional/tatap muka menuju online atau pembelajaran via daring dari rumah/ home learning yang dilaksanakan melalui pembelajaran online atau disebut dengan pembelajaran jarak jauh (PJJ). Pembelajaran daring merupakan pembelajaran yang menggunakan akses internet untuk menghasilkan berbagai jenis interaksi dalam proses pembelajaran artinya dengan adanya pembelajaran daring guru dan peserta didik sama-sama belajar untuk memanfaatkan teknologi informasi sebagai media pembelajaran. Rahayu (2020) dalam Journal of Educational Science menyatakan bahwa pembelajaran jarak jauh secara online juga mampu menumbuhkan kemandirian belajar siswa/mahasiswa belajar tanpa bimbingan langsung dari guru/dosen sehingga siswa secara secara mandiri mampu mencari dan menemukan informasi mengenai materi pelajaranan/kuliah dan tugas-tugas yang diberikan kepadanya.

Dengan terjadi perubahan bentuk pembelajaran dari yang konvensional menuju online, tentu akan merubah banyak hal, terutama strategi yang harus dilakukan oleh Guru sebagai tenaga pendidik yang merupakan ujung tombak dalam sebuah proses pembelajaran. Dalam hal ini, hambatan dalam pelaksanaan proses pembelajaran terlebih untuk sekolah tingkat SMA yang biasanya selalu mengedepankan kegiatan penguasaan iptek menjadi isu yang harus dipecahkan. Demikian pula untuk mata pelajaran yang mengedepankan etika, sikap spiritual dan sikap sosial, seperti mata Pelajaran Pendidikan Agama Hindu dan Budi Pekerti memerlukan formula, strategi dan model yang tepat sehingga pembelajaran tetap berlangsung efektif di tengah Pandemi Covid-19.

Hasil studi pendahulu yang dilakukan oleh peneliti menunjukkan bahwa pembelajaran Pendidikan agama Hindu di SMA Negeri 1 Karangasem selama ini 
disampaikan oleh guru masih menggunakan metode konvensional dimana pembelajaran lebih menekankan pada product oriented daripada process oriented tanpa memberikan contoh yang nyata dalam proses pembelajaran, sehingga menyebabkan kurangnya pemahaman peserta didik terhadap teologi dan nilai pendidikan agama Hindu yang terkandung didalammnya. Sumayana (2015) menyatakan bahwa salah satu aktor utama dalam mewujudkan kecerdasan manusia adalah guru, sehingga guru menjadi salah satu faktor utama dalam menentukan keberhasilan siswa.

Sebagai tambahan luaran pendidikan keagamaan terutang dalam Peraturan Menteri Agama Republik Indonesia Nomor 16 Tahun 2010 dimana pendidikan agama ditetapkan sebagai "pendidikan yang memberikan pengetahuan dan membentuk sikap, kepribadian dan keterampilan peserta didik dalam mengamalkan ajaran agamanya" Selanjutnya dalam Peraturan Pemerintah Republik Indonesia Nomor 55 Tahun 2007 menyebutkan bahwa pendidikan agama berfungsi membentuk manusia Indonesia yang beriman dan bertakwa kepada Tuhan Yang Maha Esa serta berakhlak mulia. Sedangkan tujuan dari pendidikan agama yaitu untuk mengembangkan kemampuan peserta didik dalam memahami, menghayati, dan mengamalkan nilai-nilai agama yang menyerasikan penguasaannya dalam ilmu pengetahuan dan teknologi.

Berdasarkan hasil wawancara dengan guru agama Hindu SMA Negeri 1 Rendang Karangasem (Asmara, wawancara 6 Juli 2021) menyatakan bahwa guru memiliki peran mulia dalam mendidik peserta didik di sekolah, guru menghadapi tantangan berat dengan adanya pandemi Covid-19, dituntut kreatif yang tinggi dalam penyampaian materi melalui media pembelajaran daring dengan menggunakan model-model pembelajaran yang inovasi dan menunjang keaktifan siswa dalam pembelajaran. dengan menggunakan modelmodel pembelajaran yang menunjang keaktifan siswa tugas guru pendidikan agama Hindu dan budi pekerti sangatlah berat karena sebagai pendidik, seorang guru harus mendidik peserta didik memiliki sikap spiritual yang tinggi, guru dituntut untuk memiliki kemampuan professional dan spiritual serta menguasai strategi pembelajaran dan media belajar secara terpadu dalam proses belajar mengajar.

Kreativitas guru Pendidikan Agama Hindu dan Budi Pekerti dalam memilih media dan metode mengajar pada masa pandemi Covid-19 sangat penting. Memilih dan menetapkan metode pembelajaran yang baik dan terarah sama dengan menetapkan tujuan pembelajaran. Memilih media dan metode pembelajaran daring menjadi bagian penting yang perlu diperhatikan dalam mengatasi tantangan guru dalam proses pembelajaran di masa Covid-19.

Sepanjang observasi di lapangan pada saat pembelajaran berlangsung realitanya guru kurang mempersiapakan perangkat pembelajaran dengan baik semestinya. Desain pembelajaran hendaknya dirancang oleh guru sebelum pembelajaran dimulai, mulai dari tujuan, strategi, model, metode, teknik dan lainnya yang sangat diperlukan dalam proses pembelajaran. Perencanaan pembelajaran yang tepat didukung dengan media yang kekinian membuat pembelajaran akan lebih efektif dan tujuan pembelajaran dapat tercapai. Ketika proses pembelajaran berlangsung secara daring banyak peserta didik yang kurang aktif dalam proses pembelajaran, guru kurang mampu menyampaikan materi pembelajaran yang berpusat pada peserta didik, guru kurang menekankan pelibatan peserta didik dalam proses pembelajaran kurang mengaitkan materi dengan kehidupan di dunia nyata, sehingga pembelajaran terkesan satu arah membuat suasana kelas kurang aktif dan motivasi peserta didik tidak muncul sepanjang pembelajaran berlangsung. Kurangnya pemahaman peserta didik terhadap materi pelajaran yang disampaikan menjadi salah satu permasalahan dalam proses pembelajaran dan memerlukan media teknologi dan komunikasi yang tepat. Tegeh (2019) menyatakan media sebagai salah satu sarana penunjang keefektifan pembelajaran pada pembelajaran daring, selanjutnya dikatakan 
salah satu media pembelajaran pada masa ini yang paling banyak digunakan adalah video pembelajaran. Video merupakan pembelajaran merupakan media audio visual merupakan media yang dinikmati indera pendengaran dan pengelihatan sebab menghasilkan bunyi dan visual. Menurut Fadli (2021) dalam jurnal Studi Kependidikan dan keislaman menjelaskan bahwa Model learning cycle 5E dengan media video pembelajaran menunjukkan efek yang signifikan dalam meningkatkan keaktifan siswa dan pemahaman pada kelas online siswa kelas VIII A MTs Pondok Tremas.

Guru Pendidikan agama Hindu dalam proses pembelajaran di masa pandemi Covid-19 memiliki ide-ide kreatif belajar melalui siaran radio edukatif RRI Denpasar dalam mengembangkan sistem pembelajaran daring bagi siswa selama belajar di rumah. Pemilihan sebuah model pembelajaran Pendidikan agama Hindu pada masa pandemi covid-19 merupakan bagian penting dalam merencanakan atau mendesain pembelajaran bagi guru, agar terjadi interaksi antara siswa dengan guru, siswa dengan siswa maupun siswa dengan sumber belajar lainnya.

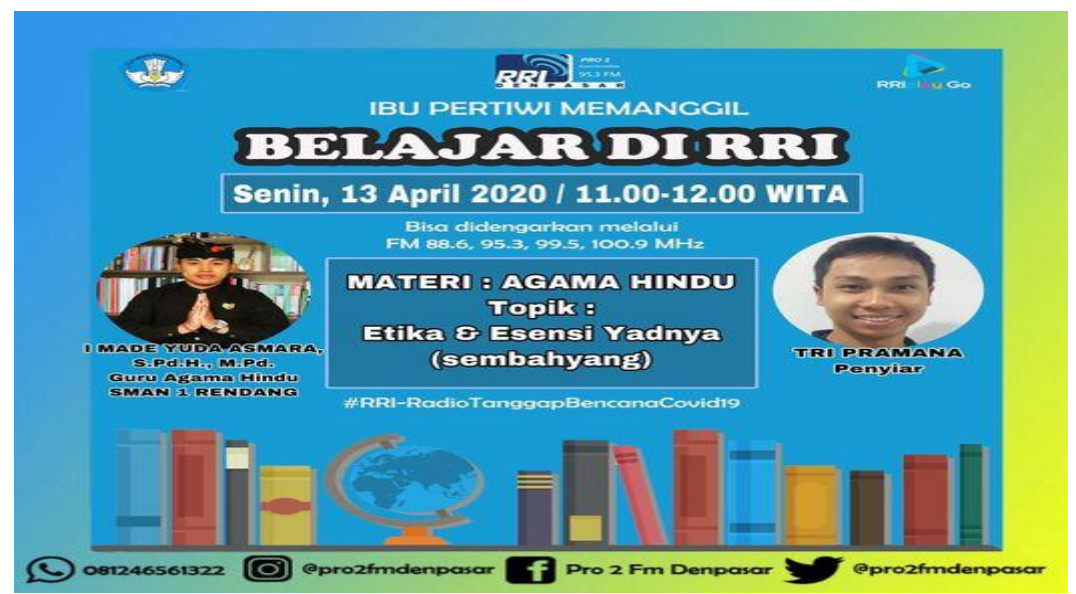

Gambar 1. Pembelajaran Pendidikan agama Hindu melalui siaran Radio Edukasi RRI Denpasar

Berdasarkan uraian tersebut di atas, maka salah satu model pembelajaran inovasi yang dirancang dan dilakukan oleh guru SMA Negeri 1 Rendang pada siswa kelas X pada masa Pandemi Covid dalam pembelajaran agama Hindu dan Budi Pekerti adalah dengan menerapkan model pembelajaran learning cycle 5E. Model Pembelajaran learning cycle $5 E$ ini dilandasi oleh pandangan kontruktivisme dari Piaget yang dimana pembelajaran harus berpusat pada siswa (student centered). Pendekatan ini juga berangapan bahwa dalam belajar pengetahuan itu dibangun sendiri oleh peserta didik dalam struktur kognitif melalui interaksi dengan lingkungannya yang sangat memperhatikan pengalaman dan pengetahuan awal siswa serta bertujuan meningkatkan pemahaman konsep siswa (Fatmawati, 2016; Pitriani, 2018; Fauzi \& Mustadi, 2019). Salah satu strategi yang mengacu pada pandangan konstruktivisme dalam pembelajaran adalah model Pembelajaran learning cycle " $5 E$ ". Model pembelajaran ini memiliki 5 tahap yang terdiri atas tahap pertama engangement/pembangkitan minat, kedua exploration/ eksplorasi, ketiga explanation/penjelasan, keempat tahap elaboration/memperluas, kelima tahap evaluation/evaluasi (Astutik, 2012). Utami (2013) menyatakan bahwa penerapan model $5 \mathrm{E}$ terbukti efektif meningkatkan rasa ingin tahu siswa melalui tema yang dibawakan serta difasilitasi melalui diskusi serta kegiatan mandiri. 

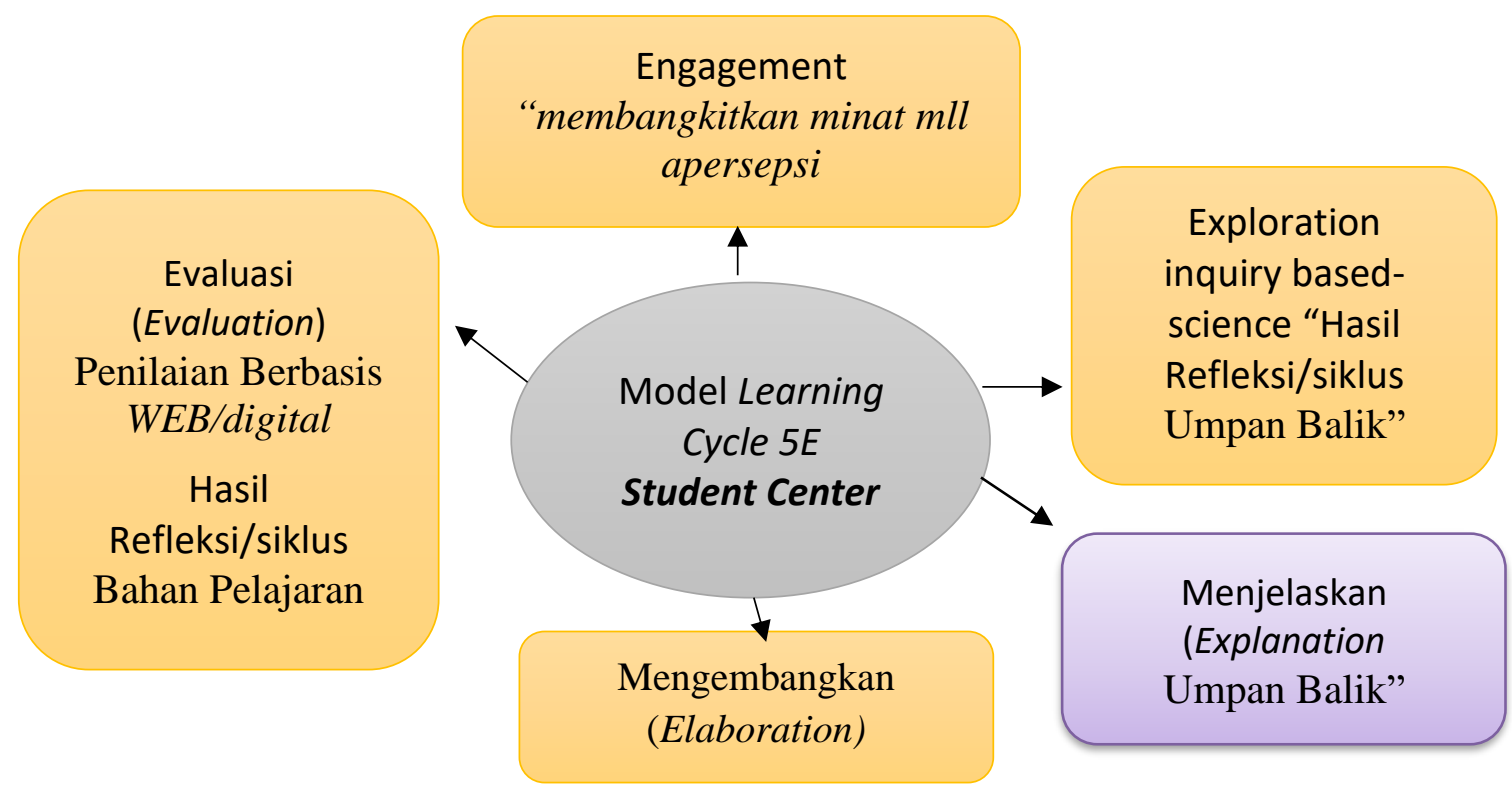

Gambar 2. Bagan Fase Model Pembelajaran Learning Cycle 5-E

Aktivitas tersebut memiliki potensi untuk memberi peluang peserta didik belajar mengkonstruksi pengetahuan agamanya (Dahar, 2016). Model pembelajaran learning cycle $5 E$ diterapkan memudahkan guru memberi pemahaman agama Hindu kepada peserta didik apalagi dikelas online. Selain itu untuk memotivasi dan menarik minat belajar peserta didik karena peserta didik diajak untuk lebih aktif dalam memperoleh pemahaman bagaimana pengetahuan agama Hindu dibangun dan digunakan dalam kehidupan seharihari sehingga peserta didik dapat menguasai kompetensi-kompetensi yang harus dicapai dalam pembelajaran.

\section{Metode}

Penelitian ini dilaksanakan menggunakan jenis kualitatif interpretatif dengan pendekatan fenomenologi, yaitu meneliti kondisi obyek secara alamiah. Sugiono (2017) menyatakan jenis penelitian kualitatif merupakan sebuah metode yang digunakan untuk mendapatkan data secara natural sesuai dengan kondisi yang sedang terjadi. Pengambilan informan dilakukan secara purposive sampling yang bertujuan untuk menentukan informan dengan pemenuhan kriteria tertentu. Berdasarkan teknik tersebut maka ditentukan informan dua orang dari guru dan tiga orang dari siswa kelas X SMA Negeri 1 Rendang. Data penelitian dikumpulkan dengan observasi berperan serta, wawancara tidak terstruktur sehingga peneliti akan lebih luas dan tidak terikat pada batasan pertanyaan dan bisa memperoleh data sesuai apa yang ada di lapangan, studi kepustakaan, dan studi dokumen. Teknik analisis data yang digunakan adalah proses diagram yang digambarkan oleh Huberman dan Miles (dalam Sugiyono 2017, Bungin, 2017) yang terdiri dari tiga kegiatan utama, yakni; reduksi data, penyajian data, dan penarikan kesimpulan/verifikasi. Prosesnya berbentuk siklus, bukan linier teknik deskriptif kualitatif dan interpretatif.

\section{Hasil dan Pembahasan}

\section{Strategi Guru dalam penerapan Learning Cycle $5 \mathrm{E}$}

Tanggung jawab sekolah untuk lebih meningkatkan perannya melalui strategi guru dalam pembelajaran pendidikan agama Hindu dan Budi Pekerti dalam penerapan model pembelajaran learning cycle $5 \mathrm{E}$ yang efektif dan efisien meliputi: (1) strategi guru dalam perencanaan pembelajaran, (2) strategi guru dalam pelaksanaan Pembelajaran, (3) strategi guru dalam evaluasi pembelajaran. 
Strategi guru dalam perencanaan pembelajaran dimulai guru merancang dan desain pembelajaran mulai dari strategi, model, metode, teknik dalam proses pembelajaran. Perencanaan pembelajaran yang tepat didukung dengan media yang inovatiaf dan variatif membuat pembelajaran akan lebih efektif dan tujuan pembelajaran dapat tercapai. Model pembelajaran inovatif dan variatif berfungsinya sebagai alat perangsang pembelajaran dari luar yang dapat membangkitkan motivasi belajar seseorang (Sardiman, 2014; Nasution 2017; Fitrhiyah, 2017). Guru pendidikan agama Hindu dan Budi Pekerti dalam merancang dan melaksanakan pembelajaran Daring pada masa pandemi covid membutuhkan strategi yang lebih dalam dan matang sehingga tujuan dari proses pembelajaran bisa tercapai. Strategi Guru Pendidikan Agama Hindu dan Budi Pekerti dalam Penerapan Model Pembelajaran Learning Cycle $5 E$ pada masa pandemi covid siswa Kelas X SMA Negeri 1 Rendang Karangasem melalui beberapa rancangan strategi yaitu; pada tahap pertama membuat rencana pelaksanaan pembelajaran (RPP) yang menggambarkan prosedur atau pengorganisasian pembelajaran untuk mencapai kompetensi dasar yang ditetapkan. Dalam menyusun perencanaan pembelajaran (RPP) daring dimana peserta didik belajar dari rumah (BDR) dengan penerapan model learning cycle $5 E$ yang berorientasi pada teori kontruktivisme pada proses pembelajarana.

Kunandar (2019) perencanaan pembelajaran berfungsi untuk menyiapkan pembelajaran yang sesuai dengan prosedur. Tahap Kedua penentuan metode yang digunakan dalam pembelajaran daring antara lain google classroom, zoom meeting whatsapps grup, Program Radio Edukasi bekerjasama dengan RRI Denpasar serta sumber belajar berupa buku paket dan LKPD sehingga dapat mendorong terjadinya proses belajar dan menciptakan suasana kelas yang aktif dan kreatif sepanjang pembelajaran. Struktur RPP Daring yang dibuat guru pendidikan agama Hindu dan Budi Pekerti terbagi menjadi tiga kegiatan yaitu; (1) tujuan pembelajaran, yaitu merumuskan tujuan pembelajaran berpedoman pada Audience, Behavior, Condition, dan Degree dengan pendekatan ilmiah (scientific approach). (2) proses pembelajaran yang meliputi; (a) pendahuluan. (b), kegiatan inti, (c) penutup), dan (3) penilaian /evaluasi yang meliputi Sikap, pengetahuan, dan keterampilan.

Penerapan model learning cycle 5E pada proses pembelajaran pendidikan Agama Hindu masa pandemi di kelas X SMA Negeri 1 Rendang yang dilaksanakan secara online dimana peserta didik belajar melaui jaringan internet dari rumah (BDR) dengan model pembelajaran learning cycle $5 E$ merupakan hal yang baru bagi peserta didik. Model pembelajaran learning cycle $5 E$ dapat meningkatkan keaktifan peserta didik dibandingkan dengan pembelajaran konvensional, diperlukan beberapa siklus belajar secara bertahap agar dapat menilai peningkatan keaktifan peserta didik dalam belajar. Mubaid, Sutrisno, \& Endahwuri (2019) dalam jurnalnya menyatakan bahwa metode 5E dapat meningkatkan pemahaman konsep siswa karena pembelajaran berpusat pada siswa membuat siswa aktif, kreatif, dan saling bekerjasama. Pada saat proses pembelajaran akan berlangsung dalam kelas melalui daring guru pendidikan agama Hindu dan Budi sebelumnya memberi informasi kepada peserta didik untuk mengakses materi menggunakan internet pada link google drive yang menambah pengalaman siswa.

Model pembelajaran learning cycle $5 E$ adalah model student-centred yang memiliki serangkaian tahapan kegiatan yang didesain secara rinci dan terukur yang mempunyai tujuan untuk memberikan kesempatan kepada peserta didik mengkontruksi pengetahuan dan pengalamannya sendiri dengan keterlibatan secara aktif mempelajari materi secara bermakna dengan bekerja dan berfikir baik secara individu maupun kelompok, sehingga pesera didik dapat menguasai kompetensi-kompetensi yang di capai dalam pembelajaran. 
Berdasarkan wawancara dengan Yuda Asmara guru pendidikan Agama Hindu dan Budi pekerti Strategi yang dilaksanakan dalam Pelaksanaan Pembelajaran agama Hindu di SMA Negeri 1 Rendang dengan model pembelajaran Learning Cycle 5E di kelas X secara online melibatkan 3 RPP dengan 10 kali pertemuan yaitu RPP 1 dengan materi pokok Nilai-nilai yadnya yang terkandung dalam kitab Ramayana ( 3x 90 menit), dan RPP ke 2 dengan materi pokok Ajaran Upaweda ( $15 x 45$ menit), dan RPP ke 3 dengan materi pokok Wariga (21x 45 menit). Pada tahap pendahuluan guru mengucapkan salam pembuka, mempersiapkan diri dengan pengaplikasian google classroom pembelajaran dan penguasaan materi ajar. Guru memberitahukan poin-poin penting yang harus diperhatikan sebelum peserta didik memperhatikan materi pembelajaran yang telah di share.

Tahapan pelaksanaa proses pembelajaran model pembelajaran Learning Cycle $5 E$ di mulai dengan langkah atau strategi yang dilaksanakan meliputi lima tahapan atau siklus yaitu;

a. Engagement merupakan tahap awal dari siklus belajar. pada tahap ini, guru berusaha membangkitkan dan mengembangkan minat dan memancing keingintahuan (curiosity) peserta didik dan pemahaman awal atas materi yang akan disampaikan, hal itu dapat dilakukan dengan memberi appersepsi sebelum pembelajaran dilaksanakan melalui ceramah dan diskusi kelas dengan peserta didik diarahkan menemukan masalahmasalah di sekitar untuk dibahas dengan memperhatikan tema pembelajaran yang akan diajarkan dan poin penting apa yang harus dicapai

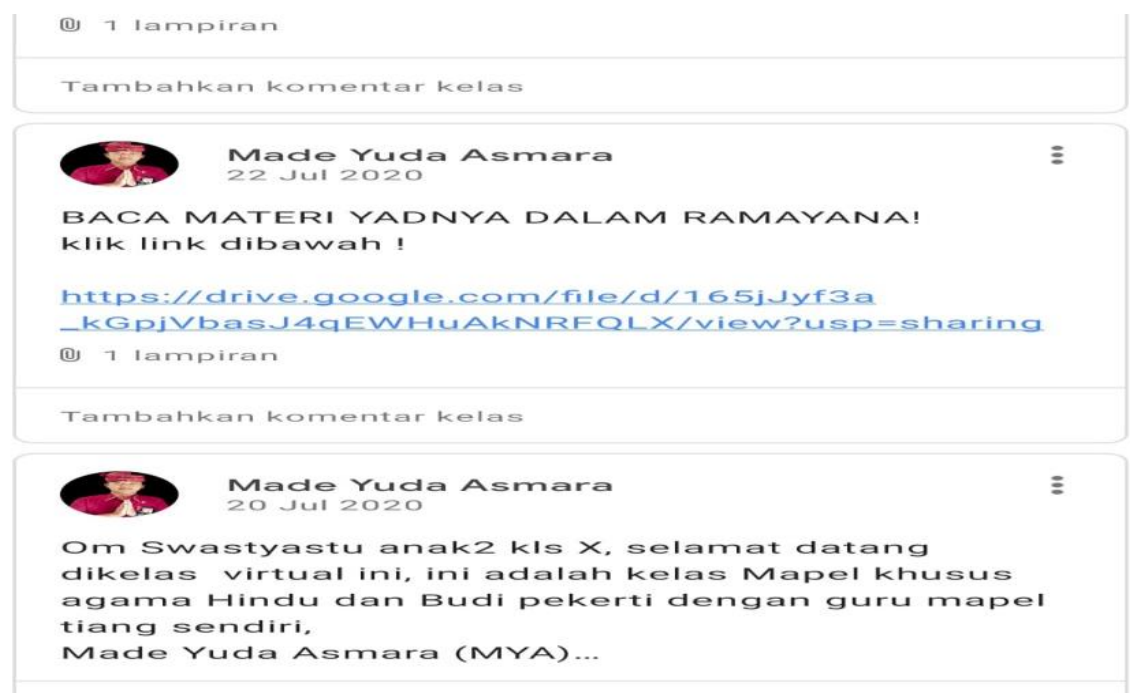

Gambar 3 Tampilan halaman aplikasi google classroom kelas X SMA Negeri 1 Rendang Karangasem

Sumber Dokumentasi peneliti 2021.

b. Exploration ; pada tahap eksplorasi ini guru menanpilkan materi yang akan dibahas disesuaikan dengan kompetensi dasar seperti pelakasanan Yadnya sehari-hari dalam ajaran Kitab Ramayana melalui link Google Drive. Langkah selanjutnya adalah dibentuknya kelompok-kelompok kecil antara 3-5 orang dan guru melaksanakan tanya jawab dan memberikan penjelasan kemudian diberi kesempatan untuk bekerja sama/diskusi secara aktif dalam kelompok kecil dan mengeksplor konsep-konsep pengetahuan yang didapat dari pengalaman belajar. Peserta didik mencari tahu sedalam-dalamnya permasalahan yang terjadi sehingga menghasilkan suatu simpulan bersama. 
c. Explanation: yaitu pada fase ini guru pengatur jalannya diskusi mendorong dan meminta peserta didik untuk menjelaskan konsep dengan bahasan dengan kalimat/ pemikiran peserta didik sendiri, mempresentasikan hasil diskusi kelompok, meminta bukti dan klarifikasi atau penjelasan jawaban-jawaban yang didapat pada kegiatan eksplorasi sebelumnya. Tujuannya untuk melihat apakah peseta didik benar-benar sudah memahami konsep dari nilai yadnya yang terdapat dalam Ramayana, dan saling mendengar secara kritis penjelasan antar peserta didik sehingga terjadi pembelajaran kombinasi antara peserta didik dengan guru juga dengan teman sejawatnya. Kolaborasi yang dilakukan dalam hal ini melalui komunikasi atau diskusi baik secara langsung dengan virtual chatroom. Tampak seperti gambar 3 dan guru sebagai fasilitator

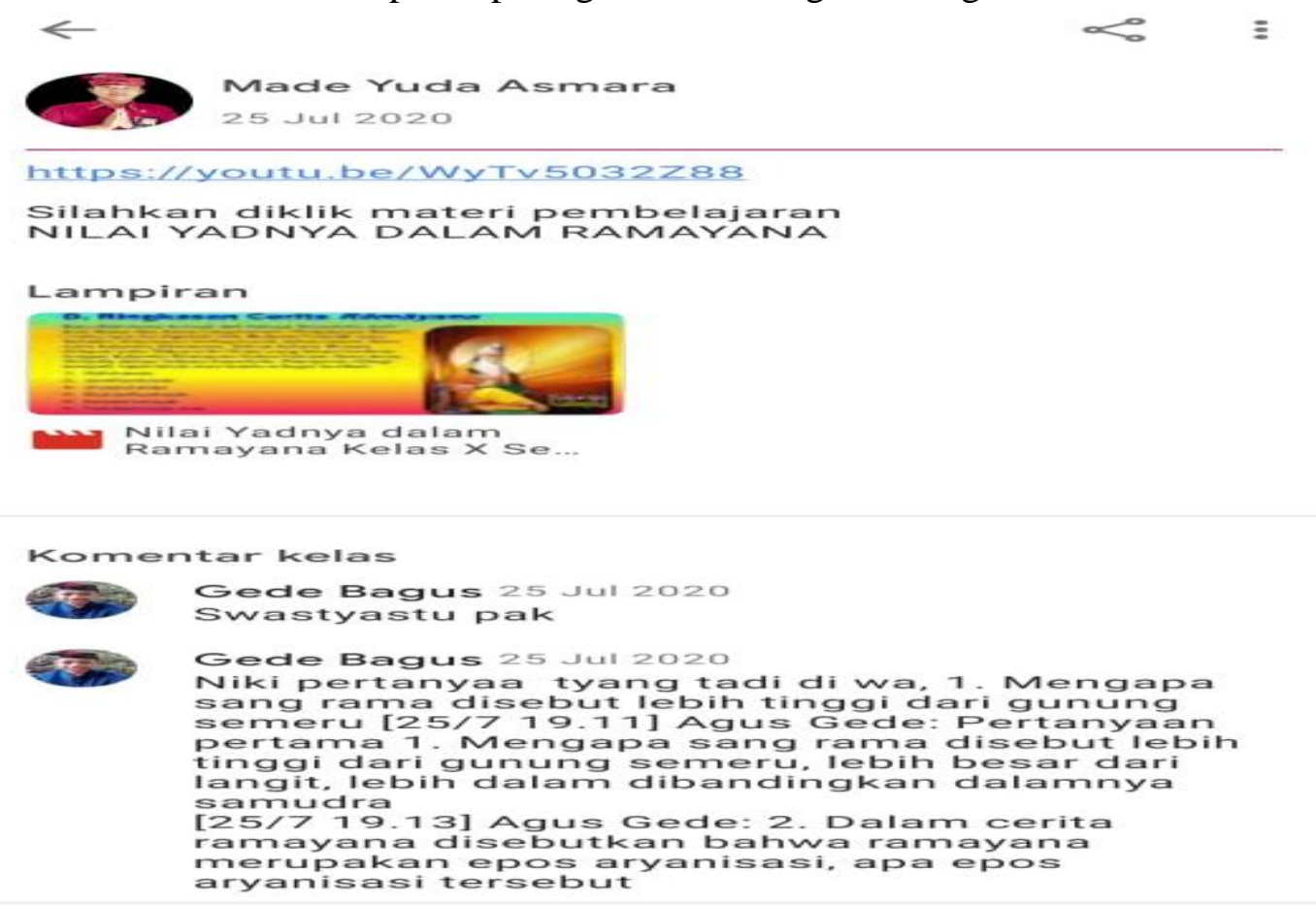

Gambar 3. Guru meminta siswa untuk mengakses materi di youtube

Sumber : Dokumentasi peneliti, Tahun 2021

Tampilan gambar platform zoom dan youtube di atas yang digunakan oleh guru pada saat memberikan topik pembelajaran yang diawali dengan memberikan tayangan video dan materi agar dapat dikritisi dan ditanggapi oleh peserta didik, dalam hal ini merupakan bagian pembelajaran inti yang dimanfaatkan agar mampu menarik perhatian peserta didik ke dalam topik yang akan dibahas.

d. Elaboration yaitu tahap pengembangan pengalaman baru dirancang untuk membantu peserta didik membangun pemahaman yang lebih luas tentang konsep yang telah didiskusikan. Peserta didik memperluas konsep yang telah di pelajari, serta dapat menjelaskan penerapannya, dan memberikan contoh positif dalam kehidupan seharihari,

e. Evaluation, pada tahap ini guru mengamati dan menilai kemampuan peserta didik dalam memahami konsep-konsep bahan ajar yang didiskusikan serta perolehan pemahaman dari informasi baru yang diterima sebagai pengalaman pengetahuan atau pemahaman peserta didik dalam belajar terhadap pengalaman-pengalaman apa yang didapat dalam menerapkan konsep baru. Kegiatan evaluasi bisa dilakukan menggunakan vicon, grup WA, zoom meeting, dan google classroom maupun bentuk kegiatan lain dimana semua siswa dapat langsung berpartisipasi aktif. 
Model pembelajaran learning cycle $5 E$ dapat meningkatkan keaktifan peserta didik dibandingkan dengan pembelajaran konvensional, diperlukan beberapa siklus belajar secara bertahap agar dapat melihat peningkatan keaktifan siswa, dengan siswa aktif juga menghasilkan peningkatan pada hasil belajar. Mubaid, Sutrisno, \& Endahwuri (2019) dalam jurnalnya menyatakan bahwa metode 5E mampu meningkatkan pemahaman konsep siswa karena pembelajaran berpusat pada siswa membuat siswa aktif, kreatif, dan saling bekerjasama

Strategi penilaian pembelajaran memegang peranan penting untuk mengetahui secara objektif dan akurat tentang kemampuan penguasaan materi pembelajaran dan keberhasilan peserta didik dalam proses pembelajaran. Guru pendidikan agama Hindu siswa kelas X di SMA Negeri 1 Rendang dengan penerapan model Learning Cycle 5E pada masa pandemi melaksanakan penilaian pembelajaran sepanjang proses pembelajaran terkait dengan informasi baru yang diterima sebagai pengalaman belajar yang didapat selama pembelajaran. Salamah (2018) menyatakan bahwa penilaian merupakan proses pengumpulan dan pengolahan infomasi untuk mengukur pencapaian hasil belajar peserta didik, selanjutnya informasi tersebut akan digunakan sebagai upaya dalam menentukan alternatif yang tepat dalam mengambil sebuah keputusan. Untuk mengukur tingkat keberhasilan yang mencakup sikap, pengetahuan dan keterampilan dalam proses pembelajaran daring, guru menggunakan aplikasi belajar seperti whatsapp grup, zoom meeting, google classroom, youtube, dan lainnya.

Berdasarkan hasil observasi dan wawancara dengan guru, maka strategi yang digunakan guru dalam hal ini adalah; (1) Strategi penilaian secara daring dengan menggunakan intrumen lembar observasi untuk menilai sikap peserta didik dalam mengikuti proses pembelajaran di kelas zoom meeting. Pada penilaian ini guru pendidikan agama Hindu melihat keaktifan peserta didik dalam diskusi sehari-hari, perilaku itu bisa terlihat dari perasaan, motivasi, emosi dari peserta didik di dalam kelas, instrumen yang digunakan adalah lembar observasi, jurnal dan catatan guru, dimana peserta didik dalam mengikuti pembelajaran daring pada akhir pembelajaran guru memberikan pertanyaan terkait dengan tema diskusi. (2) Strategi Portofolio, dalam strategi ini guru memberikan tugas harian kepada peserta didik. Kumpulan hasil karya peserta didik digunakan sebagai bahan untuk menilai sejauh mana ketercapaian peserta didik dalam memahami kompetensi dasar dan mengukur peningkatan kemandirian peserta didik dengan belajar secara daring dari rumah. Selanjutnya tugas dikumpul ke sekolah dengan tetap melaksanakan protokol kesehatan. Pemberian tugas merupakan salah satu acuan dalam melaksanakan penilaian pembelajaran karena tugas yang diberikan guru berdasarkan materi yang telah disampaikan sebelumnya untuk mengetahui kemampuan peserta didik. Pengumpulan tugas-tugas peserta didik dinilai disini guru melakukan penilaian secara terus menerus karena sebagai refleksi perkembangan berbagai kompetensi peserta didik. Selain itu juga untuk mengukur tingkat perkembangan kemajuan peserta didik. (3) Strategi pemberian tugas, dimana tugas selanjutnya dikumpul melalui aplikasi Google classroom, dimana peserta didik memberikan komentar terkait dengan materi yang diberikan oleh guru, selanjutnya guru membuat fom absen dan peserta didik wajib mengisi absen tersebut. Pengisian kehadiran peserta didik sangat penting didata oleh guru karena merupakan bukti autentik sebagai dasar untuk membantu penilaian dalam proses pembelajaran. Hal ini dikuatkan oleh Siswanto (2019) yang menyatakan bahwa absensi merupakan bukti bahwa peserta didik tersebut telah hadir dalam suatu pelajaran yang dilakukan di dalam kelas, (4) Strategi dengan memberikan soal berbentuk tes essay yang tertuang googleforms yang didalamnya sudah ada kunci jawaban dan nilainya untuk memudahkan guru dan peseta didik melihat nilainya langsung. Penilaian dalam bentuk tes merupakan himpunan pertanyaan yang harus dijawab, atau ditanggapi oleh peserta tes. Tes tersebut digunakan 
untuk mengukur sejauh mana peserta didik telah menguasai pelajaran dari proses pembelajaran yang telah dilalui yang meliputi aspek pengetahuan, sikap, dan keterampilan (Ahmad, 2020). Penilaian pengetahuan bisa juga diperoleh dengan cara penugasan dan juga tes lisan, sedangkan untuk memperoleh nilai keterampilan bisa dilakukan dengan tes praktik dan proyek Mustafa (2019). Penilaian berdasarkan kehadiran peserta didik saat pembelajaran daring. Penilaian ini dilihat dari rajinnya peserta didik dalam pembelajaran Daring.

\section{Kendala yang dihadapi Guru Pendidikan Agama Hindu dalam Penerapan Model Pembelajaran Learning cycle 5E siswa kelas X pada masa Pandemi Covid di SMA Negeri 1 Rendang.}

Model Pembelajaran Learning cycle 5E dengan paradigma kontruktivisme pada dasarnya menekankan pentingnya peserta didik membangun sendiri pengetahuannya melalui keterlibatan dalam proses belajar mengajar, yang mana proses belajar mengajar lebih berpusat pada siswa (student centered) dari pada teacher centered, guru berperan sebagai fasilitator. Learning cycle 5E juga meningkatkan interaksi antara peserta didik dengan guru, peserta didik dengan teman sejawatnya, serta peserta didik dengan sumber belajar lainnya.

Model Pembelajaran Learning cycle 5E merupakan rangkaian kegiatan lima fase yaitu engagement, exploration, explanation, elaboration, evaluation yang dibentuk sedemikian rupa sehingga peserta didik secara langsung maupun tidak langsung berhubungan dengan pengalaman sehari-hari yang dialami untuk mengkontruksi pengetahuan dan pengalaman mereka sendiri dengan keterlibatan secara aktif dan bermakna dengan bekerja dan berfikir baik secara individu maupun kelompok, sehingga dapat menguasai kompetensi yang harus di capai dalam pembelajaran. Kania (2016) menyatakan bahwa dalam pembelajaran Learning Cycle 5E menuntut peserta didik untuk berperan aktif. . Pelaksanaan proses pembelajaran daring dengan penerapan model pembelajaran learning cycle $5 \mathrm{E}$ pada masa pandemi covid telah merubah iklim belajar peserta didik dari konvensional/offline berubah ke online. Sari (2021) menyatakan bahwa pembelajaran daring atau online merupakan pembalajaran berdasarkan teknologi yang bahan belajarnya dikirim secara elektronik kepada peserta didik dari jarak jauh dan menggunakan jaringan computer. Pembelajaran online dinilai merupakan cara yang paling efektif yang dilakukan untuk saat ini (Wijoyo, 2021).

Dengan sistem pembelajaran daring dimana peserta didik belajar dari rumah tentu banyak hambatan yang dialami baik oleh peserta didik maupun oleh guru, berdasarkan hasil observasi dan wawancara dengan dua orang guru pendidikan agama Hindu dan tiga orang peserta didik maka hambatan yang dialami pada saat pembelajaran daring pada mata pelajaran pendidikan agama Hindu dipengaruhi oleh dua faktor yaitu faktor internal dan eksternal. Faktor internal berasal dari diri sendiri guru dan peserta didik. Faktor internal adalah segala sesuatu yang terdapat dalam diri yang telah dibawa sejak lahir, seperti minat yang dimiliki, emosional yang dirasakan serta potensi yang dimiliki baik itu yang bersifat kejiwaan maupun bersifat kebutuhan, Sarwono (2018).

Faktor internal dari peserta didik hasil wawancara dan observasi bahwa pembelajaran daring ini memiliki tingkat kendala yang lebih dibandingkan dengan pembelajaran konvensional anatara lain; masalah koneksi jaringan internet dan signal yang tidak stabil merupakan kendala terbesar yang dialami baik peserta didik dan guru, hal ini disebabkan letak geografis wilayah SMA Negeri 1 Rendang di Desa Rendang berada di daerah pegunungan yang tidak terjangkau signal internet yang bagus dan kuota internet yang harus selalu ada. Mahal biaya internet di daerah tempat tinggal peserta didik, dan keterbatasan sarana pembelajaran seperti laptop, Handphone, dan beberapa peserta didik 
kurang siap mengoperasikan sistem pembelajaran daring dengan cepat, dan menunjukkan adanya kecenderungan lebih senang menerima informasi materi pelajaran dari guru secara konvensional. Hasil ini ditunjang oleh hasil penelitian Roman \& Plopeanu (2021) yang menyatakan bahwa siswa menghadapi permasalahan terkait akses internet yang kurang memuaskan, waktu yang kurang mencukupi karena masalah keluarga dan ruang belajar yang kurang memadai dirumah.

Sebagian besar peserta didik kurang termotivasi belajar dan keinginannya menerima informasi materi dari satu sumber hasil diskusi dengan temen sejawat, ini disebabkan oleh belum terbiasa belajar aktif, kreatif, dan inovatif seperti bertanya, menjawab, mengemukakan pendapat, dan menemukan konsep sendiri melalui penyelidikan atau penemuan, sehingga berakibat belum mampunya peserta didik berfikir secara kritis selama mengikuti pembelajaran. Kurangnya kesadaran untuk belajar secara mandiri dan memanfaatkan sumber belajar yang ada untuk mencari dan menggali sendiri informasi baru terkait materi pembelajaran sehingga mengakibatnya keringnya pengetahuan yang dimiliki oleh peserta didik.

Faktor lain yang berkontribusi adalah faktor psikologis seperti karakter peserta didik yang pendiam, tidak mau bersosialisasi, kurang terbuka dan sulit mengutarakan pendapat maupun keinginan serta masalahnya. Banyak peserta didik merasa jenuh belajar di rumah. Hal tersebut disebabkan selain lingkungan rumah kurang mendukung juga kurangnya bersosialisasi secara langsung dengan teman-temannya. Kurangnya pemahaman peserta didik terhadap materi karena keterbatasan waktu dan literature yang mereka baca, dan kurang disiplinnya peserta didik dalam memulai pembelajaran, dalam peroses pembelajaran sering out camera, begitu juga dalam pengumpulan tugas banyak yang terlambat merupakan hambatan bagi guru dalam menuntaskan materi pembelajaran.

Guru merasa kewalahan dan kelelahan memeriksan tugas harian, diskusi, ujian tengah semester, ujian akhir semester karena mengoreksi memerlukan waktu yang sangat panjang dan memerlukan konsentrasi penuh supaya penilaian valid apalagi kalau ada peserta didik yang mengalami keterlambatan atau tidak tepat waktu dalam menumpulkan tugas.

Pada saat guru melaksanakan evaluasi sangat sulit mendikteksi keabsahan pekerjaan peserta didik dan guru tidak mengetahui apakah tugas dan ujian yang dikerjakan benar-benar dikerjakan sendiri dan benar dipahami atau hanya merupakan duplikasi dari sumber internet. Komunikasi guru yang sangat terbatas dengan peserta didik dan orangtunya berakibat pada materi yang sangat sulit dipahami menjadi berlalu karena terbatasnya komunikasi. Guru merasa pembelajaran secara daring kurang maksimal hal tersebut disebabkan guru tidak bisa menyampaikan materi dengan maksimal, guru tidak bisa melihat perkembangan pemahaman dan penguasaan materi pada peserta didik sehingga apa yang didiskusikan dan di hasilnya kurang tepat sasaran pada pencapaikan kompetensi dasar.

Hasil wawancara dengan beberapa peserta didik dan guru menyatakan bahawa kendala dari faktor eksternal yang dialami pada saat pembelajaran daring yaitu; masalah dalam lingkungan keluarga di rumah. Dalam hal ini ruang belajar yang kurang memadai dirumah, banyak orang tua yang sengaja meminta bantuan kepada anaknya untuk membantu mengerjakan pekerjaan rumah, seperti berjualan, jadi belajar sambil berjualan membuat siswa kurang fokus. Aktivitas di lingkungan sekitar rumah atau masyarakat sering melibatkan masyarakat untuk kegiatan di desa yang dapat menganggu kenyamanan menyebabkan distraksi yang cukup banyak mulai dari distraksi suara, pandangan yang bisa berpengaruh pada perkembangan otak seperti meningkatkan stres, tidak ada kestabilan emosi dan dalam jangka panjang akan berpengaruh terhadap kesehatan fisik. 
Dengan penerapan model pembelajaran Learning Cycle 5E di masa pandemi Covid menjadikan pembelajaran lebih berpusat pada peserta didik mampu mengeksplorasi materi secara luas di dunia maya sehingga lebih termotivasi dalam menyelesaikan tugas dan memenukan hal yang baru dalam menyelesaikan masalah dalam diskusi terkait matri pembelajaran dan partisipasi peserta didik dalam menyelesaikan tugas lebih baik, hal ini ditunjang Faisal (2021) dalam jurnal Studi Islam menyatakan bahwa Partisipasi siswa dalam pembelajaran saat menggunakan model pembelajaran Learning Cycle 5E pada masa pandemi Covid-19 mencapai $>80 \%$, sehingga model Learning Cycle 5E dapat digunakan pada masa pandemi Covid-19. Oleh karena itu seorang membutuhkan kreativitas dan inovasi serta memaksimalkan waktu yang tersedia.

Dari uraian di atas diharapkan bisa menjadi evaluasi untuk guru dan sekolah terkait dengan kesulitan yang dialami oleh siswa selama pembelajaran daring sesuai dengan teori belajar kontruktivisme dari Piaget bahwa belajar yaitu mengembangkan aspek kognitif yaitu meliputi struktur, isi dan fungsi. Struktur yaitu kemampuan intelektual tinggi yang dimiliki oleh manusia untuk memecahkan masalah, isi yaitu respon yang dimiliki secara khas yang dimiliki oleh individu dalam memecahkan masalah sedangkan fungsi yaitu perkembangan intelektual yang meliputi adaptasi dan organisasi (Arikunto, 2015).

\section{Implikasi Penerapan model pembelajaran model pembelajaran learning cycle $5 E$}

Penerapan model pembelajaran learning cycle $5 E$ dalam pembelajaran pendidikan agama dan Budi Pekerti Hindu pada pandemi covid terhadap siswa Kelas X SMA Negeri 1 Rendang Karangasem terorganisir dengan baik sehingga peserta didik dapat menguasai kompetensi-kompetensi yang harus dicapai dengan cara berperan aktif dalam pembelajaran (Sari, 2015; Shofiah, 2018; Yuliati, 2015). Model ini berorientasi pada pembelajaran kontruktivisme (constructivist approach) yang sangat memperhatikan pengalaman dan pengetahuan awal peserta didik dengan tujuan meningkatkan pemahaman konsep peserta didik (Fatmawati, 2016; Fauzi \& Mustadi, 2019; Pitriani, 2018). Pembelajaran online/daring merupakan model pembelajaran yang difasilitasi dan didukung oleh pemanfaatan teknologi informasi dan komunikasi yang diterapkan di bidang pendidikan dalam bentuk dunia maya, oleh karenanya mendesain pembelajaran secara online merupakan tantangan besar bagi guru agar belajar menjadi efektif dan efesien. Penerapan learning cycle $5 E$ dalam pembelajaran agama Hindu pada masa pandemi covid di SMA Negeri 1 Rendang mempunyai dampak yang signifikan yaitu: meningkatnya cara berpikir kritis peserta didik dalam mempelajari dan menemukan konsep materi secara mandiri dan mampu menggunakan pemikiran dan idenya untuk dimunculkan pengetahun yang kritis serta mempresentasikannya dalam diskusi kelompok. Strategi yang berpusat pada siswa dengan guru sebagai fasilitator membuat pembelajaran menjadi mudah, jujur, dan terbuka dalam kegiatan belajar mengajar. Informasi yang didapat bukan dari guru saja, tetapi siswa dapat mencari dan menemukan informasi sendiri

\section{Peningkatan Motivasi Kreatifitas Dalam Pembelajaran}

Pembelajaran aktif secara otomatis mengajak peserta didik untuk mengeluarkan keterampilan berkreativitas dan termotivasi untuk menemukan sendiri konsep dasar materi pembelajaran sesuai dengan kompetensi dasar sesuai kemampuan yang dimiliki peserta didik. Kaitannya dengan pembelajaran di sekolah ketika guru mendesain pembelajaran aktif dengan tujuan siswa belajar kreatif. Handarini \& Wulandari (2020) menyatakan tujuan pembelajaran secara daring yaitu memberikan layanan pembelajaran bermutu dalam jaringan yang bersifat masif dan terbuka untuk menjangkau lebih banyak dan lebih luas peminat belajar. Penerapan model pembelajaran Learning Cycle 5E di masa pandemi Covid-19 menjadikan pembelajaran lebih berpusat pada peserta didik. Peserta didik 
mampu mengeksplorasi materi secara luas di dunia maya yang mudah diakses sehingga mampu meningkatkan motivasi berkreativitas dan keaktifan pemahaman pada kelas online.

Model pembelajaran Learning Cycle 5E adalah salah satu model student-centred yang memiliki serangkaian tahapan kegiatan yang didesain secara rinci dan terukur dengan tujuan utamanya menumbuhkan kemampuan dan kemahiran berkomunikasi antar peserta didik sepanjang proses pembelajaran. Penerapan Model pembelajaran ini berimplikasi pada meningkatkan Rasa Cinta Kasih pada setiap umat manusia Cinta kasih sebagai esensi dari ajaran tat tvam asi diterapkan dalam segala tindakan peserta didik dalam proses pembelajaran untuk mewujudkan keharmonisan diantara manusia dan semua makhluk hidup ciptaan Tuhan. Hal ini terlihat pada saat observasi di lapangan dan wawancara dengan peserta didik bahwa pada saat fase explanation (penjelasan), presentasi hasil diskusi dan menjelaskan hasil temuan menggunakan kalimat siswa sendiri. Guru mengarahkan agar diskusi berjalan dengan lancar, peserta didik yang lainnya mendengarkan, menyanggah jika ada jawaban yang kurang tepat ingin berpendapat jawaban. Lanjut mengkomunikasikan hasil simpulannya pada teman kelompok lain yang tergabung dalam zoom meeting. Setelah selesai presentasi guru dan paserta didik memberikan applause sebagai rasa terimakasih dan keaktifan terhadap apa yang telah disampaikan . Hal ini sejalan dengan pendapat Astriani, dkk (2016) yang menyatakan bahwa model pembelajaran Learning cycle 5e dapat mengingkatkan keaktifan peserta didik dalam belajar, sehingga dapat berkonsentrasi mengikuti pembelajaran berdampak pada sikap sosial siswa yang meningkat karena dalam pembelajaran siswaselalu berkomunikasi atau berinteraksi baik dengan guru maupun dengan siswa yang lain.

\section{Kesimpulan}

Berdasarkan uraian dan pembahasan di atas Strategi guru agama Hindu dalam penerapan model pembelajaran learning cycle 5E pada masa pandemi covid siswa kelas X SMAN 1 Rendang dapat disimpulkan bahwa Strategi dapat dibagi menjadi tiga tahapan proses yaitu; (1) strategi guru dalam perencanaan pembelajaran yang meliputi: perumusan tujuan pembelajaran, rancangan pembelajaran, menentukan materi yang disampaikan, mempersiapkan sumber dan media, serta memasukan tahap-tahapan pembelajaran learning cycle 5E kedalam RPP. (2) strategi guru dalam pelaksanaan pembelajaran learning cycle $5 \mathrm{E}$ dengan menerapkan lima fase yaitu: engagement, exploration, explanation, elaboration, dan evaluation, (3) strategi guru dalam evaluasi pembelajaran meliputi tiga komponen: Strategi penilaian secara Daring melihat keaktifan peserta didik dalam diskusi sehari-hari, prilaku terlihat dari perasaan, motivasi, emosi dari peserta didik dan menjawab pertanyaan terkait dengan tema diskusi dengan menggunakan intrumen lembar observasi melalui zoom meeting. Strategi Portofolio, dengan memeriksa, menilai dan mengukur kumpulan hasil karya peserta didik untuk mengetahui peningkatan ketercapaian kompetensi, kemandirian, dan perkembangan kemajuan peserta didik. Strategi pemberian tugas yang dikumpul melalui aplikasi Google classroom, dimana peserta didik memberikan komentar terkait dengan materi yang diberikan oleh guru, selanjutnya guru membuat fom absen. Strategi dengan memberikan soal berbentuk tes essay yang tertuang googlefoms yang didalamnya sudah ada kunci jawaban dan nilainnya untuk memudahkan guru dan peseta didik melihat nilainya langsung.

Kendala guru dengan penerapan model pembelajaran learning cycle 5E pada masa pandemi covid pada siswa kelas X SMA Negeri 1 Rendang yaitu: hambatan internal berasal dari siswa dan guru itu sendiri seperti koneksi jaringan internet dan signal yang tidak stabil karena letak geografis SMA Negeri 1 Rendang di daerah pegunungan, kuota internet yang harus selalu ada, keterbatasan pemilikan sarana pembelajaran(laptop, 
Handphone), kurang siapnya mengoperasikan sistem pembelajaran daring dengan cepat, faktor psikologi/ karakter peserta didik, waktu yang tersedia cukup singkat sehingga guru kewalahan. Kendala eksternal berasal dari lingkungan keluarga di rumah, dan masyarakat. Pada lingkungan keluarga di rumah ruang belajar yang kurang memadai, banyak orang tua yang sengaja meminta bantuan kepada anaknya untuk membantu mengerjakan pekerjaan rumah, seperti berjualan, sehingga kurang terfokus mengikuti proses pembelajaran. Lingkungan sosial dan lingkungan alam. Kegiatan di desa yang padat sering melibatkan masyarakat yang dapat menganggu kenyamanan menyebabkan distraksi suara, pandangan yang bisa berpengaruh pada perkembangan otak seperti meningkatkan stres, tidak ada kestabilan emosi berpengaruh terhadap kesehatan fisik.

Implikasi penerapan model pembelajaran learning cycle 5E di SMA Negeri 1 Rendang adalah meningkatnya kemampuan berpikir kritis, meningkatkan motivasi, kreativitas, rasa cinta kasih sebagai esensi dari ajaran tat tvam asi yang diterapkan dalam segala tindakan peserta didik dalam proses pembelajaran untuk mewujudkan harmoni.

\section{Daftar Pustaka}

Ahmad,I.F (2020). Asesmen Alternatif Dalam Pembelajaran Jarak Jauh Pada Masa Darurat Penyebaran Coronavirus Disease (Covid-19) di Indonesia. Pedagogik: Jurnal Pendidikan, 7(1), 195-222.

Arikunto, S. (2015). Dasar-dasar Evaluasi Pendidikan (Edisi 2). Jakarta :PT Bumi Aksara. Asmuni. (2020). Penerapan Model Pembelajaran Learning Cycle 5E Untuk Meningkatkan Aktivitas Dan Penguasaan Konsep Siswa Pada Mata Pelajaran PAI dan Budi Pekerti di SMA Negeri 1 Selong, Jurnal Pedagogy,7(3)

Astriani, Dyah, Istiqamah. (2016). Model Pembelajaran Learning Cycle 5E: Mengaktifkan Siswa pada Materi Suhudan Perubahannya. Jurnal Penelitian Pendidikan IPA, $01(2)$

Astutik, S. (2012). Meningkatkan Hasil Belajar Siswa dengan Model Siklus Belajar Learning Cycle 5E berbasis Eksperimen pada Pembelajaran Sains di SDN Patrang I Jember. Jurnal Ilmu Pendidikan Sekolah Dasar,1. 144-145.

Bungin,Burhan.(2017).Metodologi Penelitian Kualitatif Aktualisasi Metodologi Kearah Ragam Varian Konterporer, Jakarta: Rajawali Press.

Dahar. Ratna Wilis (2016).Teori-Teori Belajar dan Pembelajaran, Jakarta: Erlangga,

Fadli, Muhammad Zul. (2021) Implementasi Model Learning Cycle 5E Berbantu Media Video Pembelajaran Di Kelas Online. AL-MURABBI: Jurnal Studi Kependidikan dan Keislaman, 8 ( 1 )

Faishal, Muhammad. (2021). Implementation Of The Learning Cycle 5e Learning Model During The Covid-19 Pandemic (Multicase Study Of Motivation And Learning Participation). MIYAH: Jurnal Studi Islam, 17 (2),179-192

Fatmawati, Laila. (2014). Peningkatan keaktifan dan pemahaman konsep IPS melalui model learning cycle 5E. Penelitian Dosen Pemula: LPP UAD.

Fatmawati,_Laila. (2016)._Pengembangan Bahan Ajar IPS Berbasis Model Learning Cycle Untuk Mendukung Kompetensi Profesional Mahasiswa PGSD. Elementary School 3 (2016) 123-134 Volume 3 nomor 1 Juli 2016. Universitas Ahmad Dahlan Yogyakarta.

Herliandry, L. D,Nurhasanah, Suban,M.E.,\&Kuswanto,H.(2020). Pembelajaran Pada Masa Pandemi Covid-19. Jurnal Teknologi Pendidikan, 22(1), 65-70. DOI: 10.21009/jtp.v22i1.15286

Kania, Dana Utami. (2016). Efektivitas Model Learning Cycle 5 E Untuk Meningkatkan Hasil Belajar Siswa Pada Mata Pelajaran IPA. Atthulab, 1(2)

Kizlik, B. (2012). Measurement, Assessment, and Evaluation. Tadarus Tarbawy. 3(1) 
Kunandar. (2019). Belajar dan Pembelajaran. Yogyakarta: Teras.

Kunandar. (2013). Penilaian Autentik (Penilaian Hasil peserta didik Berdasarkan Kurikulum 2013) Suatu Pendekatan Praktis. Jakarta: Raja Grafindo

Majid,A. (2014). Strategi Pembelajaran Terpadu. Bandung: Remaja Rosdakarya.

Puspitorini, F. (2020). Strategi Pembelajaran Di Perguruan Tinggi Pada Masa Pandemi. 1(1), 99-106.

Rahayu, S \& Firman, S. (2020). Pembelajaran Online di Tengah Pandemi Covid-19. Indonesian

Journal of Educational Science (IJES), 2(2), 81-89

Roman,M.,\& Plopeanu,A.P.(2021).The Effectiveness of the Emergency ELearning During Covid-19 Pandemic.The Case of Higher Education in Economics in Romania. International Review of Economics Education, 37(54) https://doi.org/10.1016/j.iree.2021.100218

Salamah, U. (2018). Penjaminan Mutu Penilaian Pendidikan. Journal EVALUASI, 2(1) https://doi.org/10.32478/evaluasi.v2i1. 79

Sardiman A.M. (2014). Interaksi dan Motivasi Belajar Mengajar. Jakarta: PT Raja grafindo

Sari,D.P.,\& Sutapa,P.(2020).Efektivitas Pembelajaran Jarak Jauh Dengan Daring Selama Pandemi Covid-19 Mata Pelajaran Pendidikan Jasmani Olahraga Dan Kesehatan (PJOK). Pediatric Critical Care Medicine

Sari,W., Rifki, A. M., \& Karmila, M. (2020). Analisis Kebijakan Pendidikan Terkait Implementasi Pembelajaran Jarak Jauh Pada Masa Darurat Covid 19. Jurnal PAPPESONA 3(2).

SE GUBERNUR BALI (2020) Nomor 09/Satgas Covid19/III/2020 Tahun 2020 (15 Maret 2020)

Setiawan, I. W. P., Suartama, I. K., \& Putri, D. A. W. M. Pengaruh Model Pembelajaran Learning Cycle 5e Berbantuan Mind Mapping Terhadap Hasil Belajar Matematika. Mimbar PGSD Undiksha.5 (2), 1-11.

Siswanto,W.A.(2019). Aplikasi Absensi Siswa Menggunakan Fingerprint dan Penjadwalan Mata Pelajaran di Sekolah Dasar Negeri Sumbernongko Jombang. UNIVERSITAS ISLAM MAJAPAHIT MOJOKERTO.

Sugiyono. (2017). Metode Penelitian Pendidikan Pendekatan Kuantitatif dan Kualitatif

Sumayana,Y.(2015).Penggunaan Metode Index Card Match Pada Mata Pelajaran IPS Pokok Bahasan Mengenal Sejarah Uang. Mimbar Sekolah Dasar, 2(1),90-98. doi:http://dx.doi.org/10.17509/mimpar-sd.v2i1.1335.

Tegeh, I Made, Simamora, A. H., \& Dwipayana, K. (2019) Pengembangan Media Video Pembelajaran Dengan Model Pengembangan 4D Pada Mata Pelajaran Agama Hindu. Jurnal Mimbar Ilmu. 24(2)

Trianto, 2010. Model Pembelajaran Terpadu.Jakarta: Bumi Aksara.

Undang-undang Nomor 20 tahun 2003 tentang Sistem Pendidikan Nasional,Jakarta: Mendiknas.

Undang-Undang Republik Indonesia Nomor 20 Tahun 2003 tentang Sistem Pendidikan Nasional Peraturan Pemerintah Republik Indonesia Nomor 55 Tahun 2007 tentang fungsi agama

Utami, B. 2013. Penerapan Siklus Belajar 5E disertai LKS Untuk Peningkatan Kualitas Proses dan Hasil Belajar Kimia. Cakrawala Pendidikan, 315-325

Wijoyo, Hadio. Dkk. (2021). Dampak Pandemi terhadap Kehidupan Manusia (Ditinjau Dari Berbagai Aspek). Sumatra: Insan Cendekia Mandiri. 